\title{
Measurement of DNA synthesis in leucocyte microcultures
}

\author{
J. H. ROBBINS
}

From the Dermatology Branch of the National Cancer Institute, National Institutes of Health, Bethesda, Maryland

SYNOPSIS A microculture technique is described in which human peripheral blood leucocytes undergo DNA synthesis in response to specific and non-specific blastogenic factors. A sensitive Millipore filter assay technique is shown to be suitable for determining the incorporation of radioactive thymidine into the DNA of the stimulated cells in these microcultures. With these methods it is possible to measure the DNA synthesis in a $50-\mu 1$ culture containing an innoculum of only $10^{5}$ leucocytes. This small culture volume, with its low number of leucocytes, therefore makes it possible to perform experiments when either the available leucocytes or blastogenic factors are in limited supply.

Measurement of the incorporation of radioactive thymidine into DNA is one of the most commonly utilized methods for evaluating the response of leucocytes to specific and non-specific blastogenic factors in vitro. The Millipore filter assay technique (Robbins, Burk, and Levis, 1970), in which the radioactive cells are collected on a Millipore filter, is one of the most rapid, efficient, and sensitive assays for measuring such incorporation. The technique has regularly been used with $500-\mu 1$ cultures originally set up with $0.5-1.0 \times 10^{6}$ human peripheral blood leucocytes. While this number of leucocytes and volume of culture fluid are considerably less than those generally used for such studies, it is often necessary to measure DNA synthesis in even smaller cultures, for example, when either the cells, blastogenic factors, or other biologically active substances to be tested are in limited supply. This report describes the suitability of the Millipore filter assay technique for, and its application to, $50-\mu 1$ cultures containing an innoculum of only $0.08-0.12 \times 10^{6}$ peripheral blood leucocytes, a volume and number of cells smaller than any previously reported to have been cultured.

\section{Method}

Fifteen $\mathrm{ml}$ of human peripheral blood is mixed with 150 units of preservative-free heparin (Panheprin, Abbott Laboratories, North Chicago, Illinois) in a $16 \times 125 \mathrm{~mm}$ screw-capped culture tube. The tube Received for publication 6 September 1972. is placed vertically in a $38^{\circ}$ incubator for one to one and a quarter hours to effect some sedimentation of the erythrocytes and is then centrifuged at approximately $50 \mathrm{~g}$ for six minutes. The resulting leucocyte-rich supernatant plasma is removed and diluted with 4 volumes of tissue culture medium 199 (Code 5477, Difco Laboratories, Detroit, Michigan) to which have been added $87.5 \mathrm{U} / \mathrm{ml}$ of penicillin and $87.5 \mu \mathrm{g} / \mathrm{ml}$ of streptomycin (Code 51082, BBL, Division of BioQuest, Cockeysville, Maryland). The resulting culture fluid usually contains $1.6-2.3 \times 10^{6}$ leucocytes $/ \mathrm{ml}$. Culture fluids containing more than $2.3 \times 10^{6}$ leucocytes $/ \mathrm{ml}$ are diluted appropriately with cell-free culture fluid. The cells are stimulated with either phytohaemagglutinin (PHA) $(2.5 \mu \mathrm{g} / \mathrm{ml}$ of culture fluid, batch E316A, Burroughs Welcome and $\mathrm{Co})$, purified tetanus toxoid $(2.0 \mu \mathrm{l} / \mathrm{ml}$ of culture fluid, lot no. $2 \mathrm{HM} 22$, Eli Lilly \& Co) or allogeneic leucocytes. Stimulation with allogeneic leucocytes was effected by mixing equal volumes of culture fluids from two allogeneic donors. Fifty $\mu \mathrm{l}$ aliquots of the variously stimulated culture fluids, as well as of unstimulated culture fluid, are placed in $6 \times 25 \mathrm{~mm}$ glass micro test tubes (cat. no. 9185-R12, A. H. Thomas Co, Philadelphia, Pennsylvania). The tubes, with room air as the gas phase, are tightly stoppered with rubber stoppers (cat. no. 8751-K10. A. H. Thomas Co) and incubated vertically at $38^{\circ} \mathrm{C}$.

At the desired time the cultures each receive 0.5 $\mu \mathrm{Ci}$ of tritiated thymidine ( ${ }^{3} \mathrm{HTdR}$ ) (thymidinemethyl- ${ }^{3} \mathrm{H}$ ), $20.4 \mathrm{Ci} / \mathrm{mmole}$, diluted to $0.5 \mathrm{mCi} / \mathrm{ml}$ of distilled water, The Radiochemical Centre, 
Amersham). After an additional incubation of three hours in the $38^{\circ}$ incubator, the $50-\mu l$ contents of each culture tube are then applied to a $13-\mathrm{mm}$ diameter, $\mathbf{0} \cdot 45$-micron pore size Millipore filter (code HAWPO13, Millipore Corp., Bedford, Massachusetts) held under vacuum in the filtering apparatus for the Millipore filter assay technique (Robbins, Burk, and Levis, 1970; Robbins, Gart, Levis, and Burk, 1972). The culture tubes then receive two rinses with saline to ensure transfer to the filters of any remaining non-adherent cells, and the filters are washed successively with $4 \mathrm{ml}$ of $5 \%$ trichloroacetic acid, $2 \mathrm{ml}$ of $95 \%$ ethanol, and $2 \mathrm{ml}$ of absolute ethanol. Each radioactive filter is then dried in vacuo, placed in $1 \mathrm{ml}$ of a Liquifluor scintillation fluid (New England Nuclear Corp, Boston, Massachusetts) held in the previously described double-vial apparatus (Robbins, Burk, and Levis, 1970) and its radioactivity is determined in a scintillation spectrometer. Background counts obtained with a filter without cells or radioactivity were approximately $15 \mathrm{cpm}$ and were not subtracted from any of the recorded data.

\section{Results and Discussion}

In order to select the size of the culture inoculum to be used in the microcultures, experiments were performed with the Millipore filter assay technique to determine its ability to detect small numbers of radioactive PHA-stimulated cells. A large batch of culture fluid, originally containing $1.8 \times 10^{6}$ leucocytes $/ \mathrm{ml}$ and $2.0 \mu \mathrm{g}$ of $\mathrm{PHA} / \mathrm{ml}$, was incubated for approximately three hours with ${ }^{3} \mathrm{HTdR}$ beginning at the 67 th hour of culture. Then, 500- $\mu 1$ aliquots were prepared by diluting the resulting radioactive culture fluid with cell-free non-radioactive culture fluid and were applied to the filters. As shown in the insert of Fig. 1, the counts per minute which were obtained from filters containing $500 \mu \mathrm{l}$ of the greatest leucocyte dilutions $(1 / 128$ and 1/64) were linearly proportional to the number of radioactive cells applied to the filters. This linearity indicates that the difference in the numbers of these cells applied to the filters did not produce different efficiencies of counting. However, filters through which were passed the undiluted (1) and halfdiluted $(1 / 2)$ leucocyte culture fluid gave counts per minute which fell below the values expected (broken line) if the recorded counts per minute had remained linearly proportional to the number of radioactive cells applied to each filter, indicating that when relatively large numbers of cells are trapped on the filters the efficiency of counting is decreased presumably because of layering of excessive cells.

When these filters were combusted in a Packard

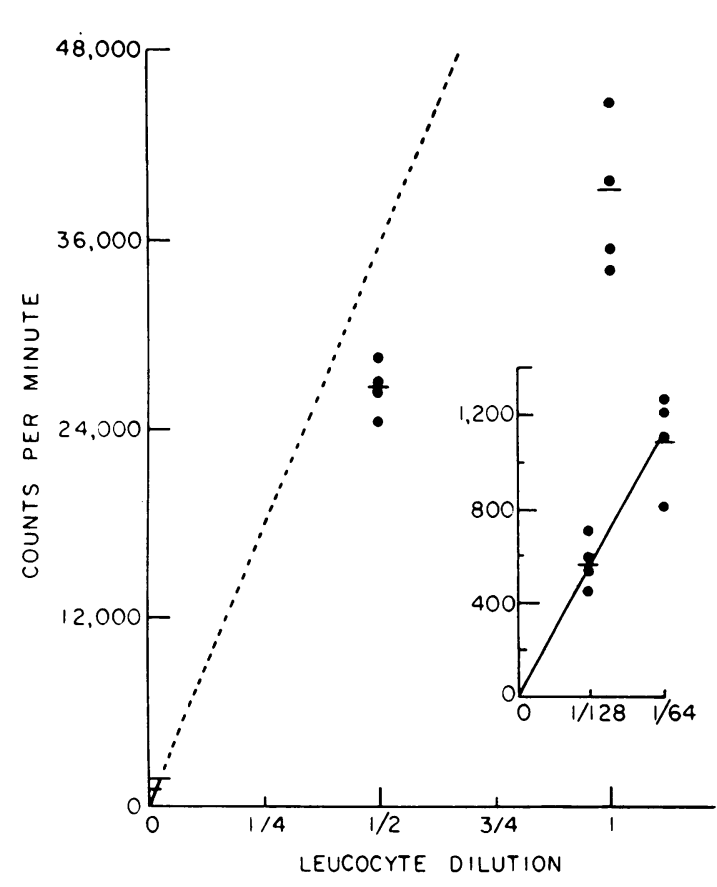

Fig. 1 Relationship between cpm recorded directly from the filters (with the double-vial technique) and concentration of leucocytes in the 500- $\mu$ l aliquots of culture fluid applied to the filters. Each horizontal bar denotes the mean of the replicate aliquots assayed. The cpm recorded for the 1/128 and 1/64 dilutions (shown in greater detail in insert) are fit adequately by the solid line which passes through the origin and which was fitted by the method of least squares. The broken line is an extrapolation of the solid line and indicates the cpm expected if the radioactivity on the filters containing the half-diluted or undiluted aliquots had been counted at the same efficiency as the filters containing the $1 / 128$ and 1/64 dilutions.

tritium sample oxidizer (Kaartinen, 1969) so that their radioactive contents, converted to tritiated water, could be counted in a homogeneous solution with a new but constant counting efficiency, the counts per minute obtained were linearly proportional to the number of radioactive cells applied to each filter (Fig. 2 and its insert), indicating that the filters had, in fact, trapped all of the radioactive cells applied to them. In other experiments in which different quantities of the undiluted radioactive culture fluid were applied to filters, it was found that the radioactivity in $50-\mu 1$ quantities was counted at the same efficiency as smaller aliquots and without cell layering effects (Robbins, Gart, Levis, and Burk, 1972). Since such 50- $\mu$ l quantities, which were one order of magnitude less than our standard cultures, 


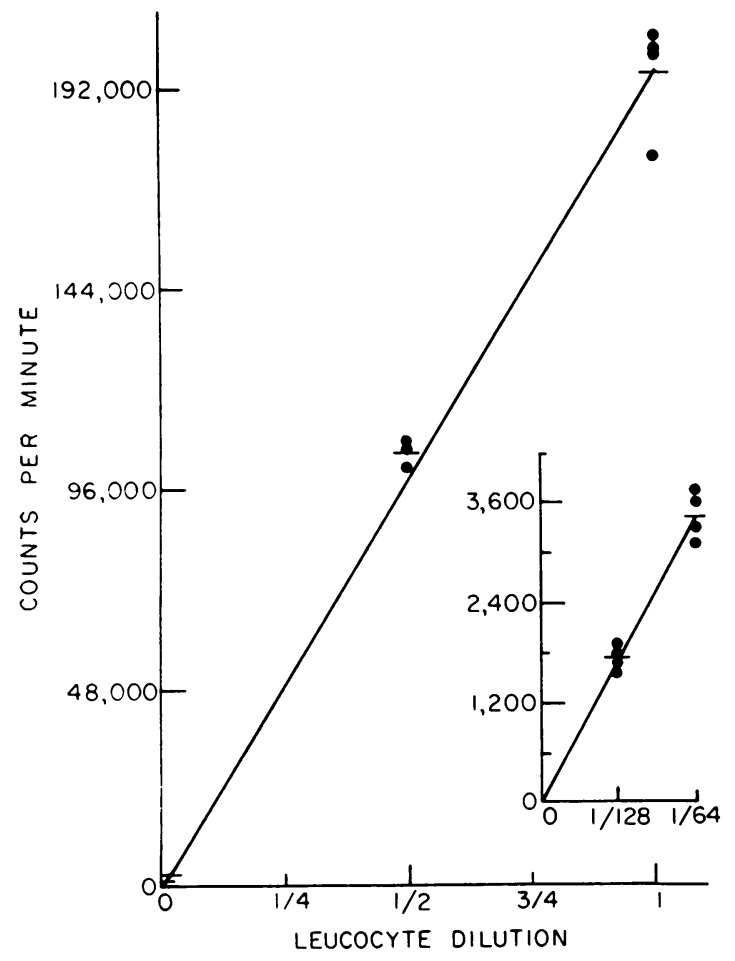

Fig. 2 Relationship obtained, using a combustion technique, between cpm recorded and different leucocyte dilutions. The filters combusted were those used for Fig. 1. The lines were fitted by the method of least squares. The figure's line fits adequately through the origin and the cpm recorded for all four leucocyte dilutions. Details of the values obtained at the 1/128 and $1 / 64$ dilutions are shown in insert.

were not affected by layering effects and gave counts well above the detectable lower limits of the filter assay system, $50 \mu \mathrm{l}$ was chosen as the volume for the microcultures.

The results in Tables I and II show that it was possible to culture successfully the $50-\mu l$ cultures and to measure the DNA synthesis occurring therein. The PHA-stimulated microcultures gave 4000 12000 counts per minute on the second or third day of culture. Responses up to 5000 counts per minute were obtained in tetanus-stimulated microcultures from individuals previously known to give good responses to that antigen. In mixed leucocyte microcultures, responses as high as 3600 counts per minute were obtained. The high values obtained in these stimulated cultures, in contrast to the low values found in the corresponding unstimulated cultures, indicate that the use of these microcultures with the Millipore filter assay technique provides a

\begin{tabular}{|c|c|c|c|c|}
\hline \multirow[t]{3}{*}{ Cell Donor } & \multicolumn{4}{|c|}{$\begin{array}{l}\text { Mean }{ }^{2} H T d R \text { Incorporation (cpm) of } \\
\text { Replicate Cultures with Indicated Blastogenic } \\
\text { Factor on }{ }^{1}\end{array}$} \\
\hline & \multicolumn{2}{|c|}{ Day 2 or 3} & \multicolumn{2}{|c|}{ Day 4, 5, or 6} \\
\hline & $\begin{array}{l}\text { No } \\
\text { Factor }\end{array}$ & $P H A^{2}$ & $\begin{array}{l}\text { No } \\
\text { Factor }\end{array}$ & $\begin{array}{l}\text { Tetanus } \\
\text { Toxoid }^{3}\end{array}$ \\
\hline $\mathrm{C}^{4}$ & $\begin{array}{l}51 \\
40 \\
47 \\
45\end{array}$ & $\begin{array}{r}10326 \\
4101 \\
5510 \\
7489\end{array}$ & $\begin{array}{l}49 \\
32\end{array}$ & $\begin{array}{l}2270 \\
4890\end{array}$ \\
\hline $\mathbf{R}$ & 43 & 6729 & & \\
\hline $\begin{array}{l}\text { J } \\
\text { D }\end{array}$ & $\begin{array}{r}178 \\
83\end{array}$ & $\begin{array}{r}11926 \\
6058\end{array}$ & 71 & 5141 \\
\hline $\mathbf{B}$ & 59 & 4665 & 30 & 392 \\
\hline
\end{tabular}

Table I ${ }^{3} H T d R$ incorporation in PHA- and antigenstimulated microcultures

${ }^{1}$ Duplicate, triplicate, or quadruplicate cultures were assayed. $22.5 \mu \mathrm{g} / \mathrm{ml}$ of culture fluid.

$32.0 \mu \mathrm{l} / \mathrm{ml}$ of culture fluid.

-The results on cells from donor $\mathrm{C}$ are from separate experiments, each conducted on a blood sample obtained on a different day.

\begin{tabular}{llc}
\hline Experiment No. & $\begin{array}{l}\text { Contents of } \\
\text { Cultures }\end{array}$ & $\begin{array}{c}\text { Mean }{ }^{3} \text { HTdR Incorporation } \\
\text { (cpm) of Replicate Cultures }\end{array}$ \\
\hline $1^{1}$ & C cells alone & 75 \\
& J cells alone & 71 \\
R cells alone & 105 \\
& C + J cells & 3694 \\
$2^{2}$ & R + J cells & 1930 \\
& B cells alone & 30 \\
$3^{3}$ & D cells alone & 70 \\
& B + D cells & 2534 \\
& C cells alone & 47 \\
R cells alone & 44 \\
& C + R cells & 3559 \\
\hline
\end{tabular}

Table II ${ }^{3}$ HTdR incorporation in mixed leucocyte microcultures

${ }^{1}$ Values are the mean cpm of quadruplicate cultures assayed on the fifth day of culture.

${ }^{2}$ Values are the mean cpm of triplicate or quadruplicate cultares assayed on the sixth day of culture.

${ }^{3}$ Values are the mean cpm of duplicate cultures assayed on the fourth day of culture.

very sensitive means for measuring the DNA synthesis induced by these blastogenic factors. While these results were given by leucocytes obtained from $15 \mathrm{ml}$ of heparinized whole blood (sufficient for about 500 microcultures), the microculture technique is well suited for, and has given essentially similar results with, leucocytes obtained from much smaller quantities of blood. Thus, this sensitive microculture technique should be extremely useful not only when blastogenic factors, but also when the amounts of blood obtainable, are in limited supply.

I wish to thank Miss R. M. Cuddy for frequent blood donations, Mrs Elaine Cowles for typing the manuscript, and Miss R. Sheats for technical assistance. 
References

Kaartinen, N. (1969). A new oxidation method for the preparation of liquid scintillation samples. Packard Technical Bulletin, No. 18, April. Packard Instrument Co., Downers Grove, Illinois.

Robbins, J. H., Burk, P. G., and Levis, W. R. (1970). Rapid and sensitive assay for D.N.A. synthesis in leucocyte cultures. Lancet, $2,98$.

Robbins, J. H., Gart, J. J., Levis, W. R., and Burk, P. G. (1972). The Millipore filter assay technique for measuring tritiated thymidine incorporation into DNA in leucocyte cultures. Clin. exp. Immunol., 11, 629-640.

\section{The November 1972 Issue}

\section{THE NOVEMBER 1972 ISSUE CONTAINS THE FOLLOWING PAPERS}

ACP Presidential Address: Medical microbiology for patient and community SIR JAMES HOWIE

The preparation of a 'metal-free' nappy and its application to metabolic balances in children F. W. ALEXANDER AND H. T. DELVES

Rapid analysis of pregnanediol in pregnancy urine W. COOPER, M. G. COYLE, AND V. K. SMITH

Standardization of clinical enzyme assays: a reference method for aspartate and alanine transaminases J. H. WILKINSON, D. N. BARON, D. W. MOSS, AND P. G. WALKER

The sea-blue histiocyte syndrome with hepatic porphyria and infectious mononucleosis $\mathrm{M}$. $\mathbf{L}$. GHOSH

Bone marrow iipofuscin K. G. A. CLARK AND W. M. DAVIDSON

The Kmif (Kveim-induced macrophage migration inhibition factor) test in sarcoidosis $w$. JONES WILlIAMS, E. PIOLI, D. J. JONES, AND M. DIGHERO

Incidence of haemagglutinating antibodies to meningococci in north-west England D. M. JONES AND BARBARA M. TOBIN

Identification and characterization of Moraxella phenylpyruvica J. J. S. SNELL, L. R. HILL, AND S. P. LAPAGE
Further study of strontium selenite and selenite $F$ broths for the isolation of Salmonella typhi P. Y. CHAU AND C. R. FORREST

Isolation of Aeromonas species from clinical sources A. W. MCCRACKEN AND R. BARKLEY

Stimulation of growth on a deficient medium of a Klebsiella aerogenes species by sulphonamide, paraamino benzoic acid, nitrofurantoin, and some other substances D. MCGHIE, J. G. P. HUTCHISON, AND R. G. FINCH

The in-vitro activity of tobramycin compared with that of other aminoglycosides PAMELA M. WATERWORTH

Computer listing of the effects of drugs on laboratory data D. S. YOUNG, D. W. THOMAS, AND R. B. FRIEDMAN

The role of operational research in clinical chemistry J. PETO, L. G. WHITBY, AND D. J. FINNEY

\section{Technical methods}

Preliminary investigation on a rapid method for the concentration and processing of extracellular blood parasites for electron microscopy R. H. CAVILL AND J. M. GOLDSMID

The localization of viable bacteria in tissue P. D. MEERS AND A. C. HUNT

Book reviews

Proceedings of the 89th general meeting of the Association of Clinical Pathologists

Copies are still available and may be obtained from the PUBLISHING MANAGER, BRITISH MEDICAL ASSOCIATION, TAVISTOCK SQUARE, LONDON, WC1H 9JR, price $£ 1 \cdot 50$. 